\title{
Adherence of Oral Microorganisms to Guided Tissue Membranes: An In Vitro Study
}

\author{
Hom-Lay Wang, ${ }^{*}$ Kuo Yuan, ${ }^{*}$ Frederick Burgett, ${ }^{*}$ Yu Shyr, ${ }^{\neq}$and Salam Syed ${ }^{s}$
}

MICROORGANISMS CAN ADHERE AND COLONIZE on an exposed guided tissue regeneration (GTR) membrane thus developing a nidus of infection. The purpose of this study was to compare early bacterial adhesion to three different GTR membranes. Expanded polytetrafluoroethylene, polyglactin 910 , and collagen were used as the test membranes. In part I of this study 15 different oral microbes were used to compare their relative ability to adhere to the membranes. Six of the most strongly adherent bacteria (Actinomyces viscosus, Actinobacillus actinomycetemcomitans, Porphyromonas gingivalis, Streptococcus mutans, Fusobacterium nucleatum, and Selenomonas sputigena) were selected for part II of this study. The membranes were placed in tubes containing broth cultures containing identical concentrations $\left(1 \times 10^{8} \mathrm{cells} / \mathrm{ml}\right)$ of these bacteria at $37^{\circ} \mathrm{C}$. Membranes were placed in tubes of media without bacteria as controls. At $4,6,12$, and 24 hours, the bacterial cultures were decanted and the membranes in the tubes were agitated gently in reduced transfer fluid (RTF) 4 times to remove non-adherent bacteria. Each tube was then sonicated for 30 seconds in $10 \mathrm{ml} \mathrm{RTF}$ to detach adherent bacteria. The detached adherent bacteria were counted using a Petroff-Hausser chamber. Data were analyzed by using the SAS program. Analysis of variance was used to test for differences between multiple means. Results showed $S$. mutans had the strongest adherence at all time points except for $P$. gingivalis which exhibited the strongest attachment to the collagen membrane at 4 and 6 hours. Selenomonas sputigena had the lowest adherence capability to all test membranes. Polyglactin 910 had significantly $(P<0.05)$ lower $S$. mutans adherence than either the ePTFE or the collagen membrane at 4 and 6 hours. The collagen membrane had significantly higher values of $S$. mutans adherence at 12 and 24 hours when compared to the other two membranes. No significant differences on $A$. actinomycetemcomitans, $A$. viscosus, $F$. nucleatum, and Selenomonas sputigena were observed when different membranes were compared. This pilot study indicated that certain bacteria adhere to GTR membranes and that $S$. mutans and $P$. gingivalis have the strongest adherence affinity of those microbes tested. I Periodontol 1994;65:211218.

Key Words: Polyglactin/microbiology; guided tissue regeneration; collagen/microbiology; polytetrafluoroethylene/microbiology; membranes, barrier/microbiology; membranes, artificial/microbiology.

Guided tissue regeneration (GTR) has been used to regain lost periodontal attachment around teeth, to repair bone dehiscence associated with dental implants, and to augment resorbed ridges. ${ }^{1-3} \mathrm{~A}$ variety of absorbable and non-absorbable biomaterials are being used clinically or are being tested

\footnotetext{
"Department of Periodontics/Prevention/Geriatrics, School of Dentistry, University of Michigan, Ann Arbor, MI.

Private practice, Tainan, Taiwan.

*Department of Biostatistics, School of Public Health, University of Michigan, Ann Arbor, MI.

¿Department of Biologic and Material Sciences.
}

experimentally for use with GTR procedures. Although attempts are made to limit the exposure of these materials to the oral environment, because of flap dehiscence or gingival recession, exposure of the GTR membrane during the healing period is a common occurrence. ${ }^{4}$ Microorganisms can adhere to and colonize exposed membranes leading to the development of a nidus of infection. Microbial adherence has been associated with infection and subsequent rejection of many biomaterials. ${ }^{5}$ Pioneering bacteria which initially adhere to biomaterials can multiply and cause infection or provide a base for co-aggregation of secondary microor- 
ganisms leading to infection. ${ }^{6}$ Furthermore, Selvig et al. reported that the extent of oral exposure and bacterial contamination of the expanded polytetrafluoroethylene (ePTFE) membrane at the time of removal may be an indicator of the long-term success or failure of the regenerative procedure. ${ }^{7}$ Therefore, the objectives of this study were to compare qualitatively the relative adherence of 15 different oral microbes to three types of GTR membranes and to compare the quantitative adherence ability of microorganisms in the initial bacterial colonization of these membranes. The microbes tested were Streptococcus mutans, Streptococcus sanguis, Actinomyces viscosus, Actinobacillus actinomycetemcomitans, Porphyromonas gingivalis, Prevotella intermedia, Prevotella melaninogenica, Fusobacterium nucleatum, Capnocytophaga ochracea, Selenomonas sputigena, Treponema denticola, Treponema vincentii, Treponema pectinovorum, Campylobacter recta and Candida albicans. The three types of GTR membranes evaluated were; ePTFE, \$ polyglactin 910 ," and collagen."

\section{MATERIALS AND METHODS}

\section{Part I. Qualitative Observation on the Microbial Adherence to GTR Membranes}

Membrane selection. Three different GTR materials were selected for this study, ePTFE, polyglactin 910, and Type I bovine collagen. ePTFE is a non-absorbable bioinert material while Polyglactin 910 and Type I collagen are absorbable in the bio-environment.

Microorganisms selection and preparation. Fifteen different organisms/oral microorganisms representing aerobes, microaerophilic or capnophilic and anaerobes were included in this study: $C$. albicans, $S$. mutans, $S$. sanguis, A. viscosus, $A$. actinomycetemcomitans, $P$. gingivalis, $P$. intermedius, $P$. melaninogenica, $F$. nucleatum, Capnocytophaga ochracea., Selenomonas sputigena., T. denticola (ATCC 35405), T. vincentii (ATCC 35580), T. pectinovorum (ATCC 33768), and C. recta. The organisms were clinical isolates from periodontitis patients preserved in frozen vials stored in liquid nitrogen at $-135^{\circ} \mathrm{C}$ except for Treponema spp. which were reference strains obtained from the American Type Culture Collection (ATCC). The organisms were defrosted, re-vitalized, and inoculated into the appropriate broth and agar media. An enriched trypticase soy agar with $2 \%$ sucrose was used as a primary culture medium for all test organisms except Treponemas which were cultivated in TYGS (trypticase-yeast-glucose-serum) broth. TYGS broth supplemented with pectin was used for T. pectinovorum. For microbial adherence study the following media were used: Trypticase soy broth with $4 \%$ sucrose for streptococci, A. viscous, and C. albicans. Schaedler broth with formate-fumarate for Campylobactor recta.

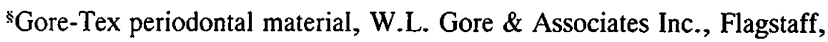
AZ.

IVicryl, Ethicon Inc., East Brunswick, NJ.

'Periobarrier, Colla-Tec Inc., Plainsbora, NJ.
Schaedler broth without supplements for the remaining bacterial species. TYGS broth media described above were used for the spirochetes. The purity of the organisms were checked under phase-contrast microscope and by standard culture tests. After the purity was ascertained, the bacteria were grown in an appropriate broth at $37^{\circ} \mathrm{C}$ either in aerobic $\left(80 \% \mathrm{~N}_{2}\right.$ and $\left.20 \% \mathrm{O}_{2}\right)$, anaerobic $\left(85 \% \mathrm{~N}_{2}, 10 \% \mathrm{CO}_{2}\right.$, and $\left.5 \% \mathrm{H}_{2}\right)$ or capnophilic $\left(10 \% \mathrm{CO}_{2}\right)$ atmosphere.

Experimental design. Membranes were cut into $6 \times 8$ $\mathrm{mm}$ rectangular form in a laminar flow hood. Both surfaces of the membrane specimens were vulnerable to bacterial exposure during immersion in a bacterial suspension. Membranes were hung in a way that the border of the material did not touch the bottom or sides of the bottle and were arranged on the same horizontal plane. Capped bottles with $80 \mathrm{ml}$ of appropriate media each containing three test membranes suspended from orthodontic wire were inoculated with log-phase pure cultures of test organisms grown in broth and incubated in aerobic, anaerobic or, capnophilic conditions at $37^{\circ} \mathrm{C}$. Identical uninoculated bottles were used as controls. Media of the inoculated bottles were changed every 24 to 48 hours depending on the growth of each microbial species as determined by turbidity. Each time the media were changed, the purity of the cultures was verified using phase-contrast microscope and standard cultural tests. If any contamination appeared in the medium, the whole bottle was discarded and the procedure repeated. Bottles were monitored daily and adherence ability was scored by a single examiner using the following visual assessment criteria: 0 , no visible adherence; 1 , adherence on less than $100 \%$ of the surface area of the membrane; 2 , adherence on $100 \%$ of the surface area of the membrane; and 3, adherence on $100 \%$ of the membrane surface and extending out from the surface. Examination of the membranes was performed by dissecting binocular microscope equipped with a zoom lens. The degradation patterns of the membranes were also observed. The examination was performed under a 30 watt light bulb* with a magnifying glass through clear fresh medium. Evaluation continued for 35 days.

\section{Part II. Quantitative Analysis of Microbial Adherence}

Membrane and bacterial selection. The same size membranes used in Part I of this study were used in Part II. The 6 species of microflora which demonstrated either strong adherence or degradation ability from the Part I study were selected for Part II. These bacteria were: S. mutans, $A$. viscosus, A. actinomycetemcomitans, $P$. gingivalis, Selenomonas sputigena, and $F$. nucleatum.

Bacterial preparation. The log phase broth cultures of selected bacteria were harvested by centrifugation at 3500 rpm for 20 minutes and resuspended in reduced transport fluid (RTF) and dispersed by a Vortex mixer** for $30 \mathrm{sec}$ -

\footnotetext{
"Bausch \& Lomb, Rochester, NY.

**American Hospital Supply, Evanston, IL.

${ }^{+\dagger}$ Branson Ultrasonic Corp., Danbury, CT.
} 
onds. The bacterial suspension was diluted and the concentration was adjusted to $10^{9}$ cells $/ \mathrm{ml}$ as determined by enumeration of cells with Petroff-Hausser chamber. In this study, every chain of $S$. mutans or clumps of actionmyces or single cells of other bacteria were counted as an unit. The bacterial suspension thus prepared was used in the quantitative adherence study.

Experimental design. Four tubes per test membrane each containing $4.5 \mathrm{ml}$ of appropriate broth medium and three pieces of the same experimental specimens were inoculated with $0.5 \mathrm{ml}$ bacterial suspension at a concentration of $10^{9}$ cells $/ \mathrm{ml}$. The final concentration of the organisms at 0 hour was $10^{8}$ cells $/ \mathrm{ml}$. Identical test tubes containing the same membrane and broth media without bacteria were used as control. All the test tubes were incubated at $37^{\circ} \mathrm{C}$ in the appropriate gaseous environments. After 4, 6, 12, and 24 hours, the media of three test tubes containing each kind of material were decanted into sterile bottles and the concentration of bacteria was counted with a Petroff-Hausser chamber. Ten milliliters $(\mathrm{ml})$ of sterile RTF were added to each test tube and agitated gently for 20 seconds. The RTF was aspirated with a sterile dropper. Thereafter, $10 \mathrm{ml}$ of fresh, sterile RTF was added into each test tube. The same procedure was repeated 4 times to remove non-adherent bacteria. Test tubes with Gram positive bacteria were sonicated at $10 \mathrm{kHz}$ for up to 30 seconds in $10 \mathrm{ml}$ RTF to dislodge adherent organisms from the membrane materials. The membranes with Gram negative bacteria were sonicated for 5 to 10 seconds to avoid possible lysis. The sonication effluent with bacteria was counted using a PetroffHausser chamber under a phase-contrast microscope. Data were calculated in terms of $10^{7}$ cells $/ \mathrm{cm}^{2}$ for each membrane.

\section{Statistical Analysis}

Experiments were run in triplicate with mean and standard deviation being calculated. Analysis of variance (ANOVA) in the SAS program was used to test among the differences for multiple means. ANOVA was used if the concentration of environmental bacteria influenced the level of bacterial adherence. The analysis was designed to test differences of the mean bacteria adherence among the types of the bacteria at each membrane and to test differences of the mean bacteria adherence among the membranes at each type of bacteria. Differences were considered significant when the ANOVA $P$ value of Bonferroni adjusted $t$ test was less than 0.05 .

\section{RESULTS}

\section{Part I. Qualitative Observation on the Microbial Adherence to GTR Membranes}

The results of the microbial adherence and degradation of different membranes are summarized in Tables 1 and 2 . Among the 15 original test microorganisms, $S$. mutans, $S$. sanguis, $A$. viscosus, $P$. melaninogenica, and Selenomonas sputigena showed the strongest adherent ability to all three
Table 1. Microbial Adherence to Membranes at day 3

\begin{tabular}{|c|c|c|c|}
\hline \multirow[b]{2}{*}{ Organism } & \multicolumn{3}{|c|}{ Adherence Score* } \\
\hline & ePTFE & Collagen & Polyglactin 910 \\
\hline S. mutans & 3 & 3 & 3 \\
\hline S. sanguis & 3 & 3 & 3 \\
\hline A. viscosus & 3 & 3 & 3 \\
\hline P. melaninogenica & 3 & 3 & 3 \\
\hline Selenomonas sputigena & 3 & 3 & 3 \\
\hline$P$. gingivalis & 3 & 1 & 1 \\
\hline P. intermedia & 2 & 3 & 1 \\
\hline F. nucleatum & 1 & 3 & 2 \\
\hline C. albicans & 0 & 2 & 0 \\
\hline $\begin{array}{l}\text { Capnocytophaga } \\
\text { ochracea }\end{array}$ & 0 & 2 & 1 \\
\hline C. recta & 1 & 0 & 0 \\
\hline $\begin{array}{l}\text { A. actinomycetemcom- } \\
\text { itans }\end{array}$ & 0 & 1 & 0 \\
\hline $\begin{array}{l}\text { T. denticola } \\
\text { (ATCC 35405) }\end{array}$ & 0 & 0 & 0 \\
\hline $\begin{array}{l}\text { T. vincentii } \\
\text { (ATCC 35580) }\end{array}$ & 0 & 0 & 0 \\
\hline $\begin{array}{l}\text { T. pectinovorum } \\
\text { (ATCC } 33768 \text { ) }\end{array}$ & 0 & 0 & 0 \\
\hline
\end{tabular}

${ }^{*} 0=$ No visible adherence; $1=$ adherence on less than $100 \%$ of the surface area of the membrane; $2=$ adherence on $100 \%$ of the surface area of the membrane; and $3=$ adherence on $100 \%$ of membrane surface and extending out from the surface.

Table 2. Species That Degraded Membranes Before Day 35

\begin{tabular}{lll}
\hline PTFE & \multicolumn{1}{c}{ Collagen } & \multicolumn{1}{c}{ Polyglactin 910} \\
\hline None & P. gingivalis & C. albicans \\
& $P$. melaninogenica & P. melaninogenica \\
& T. denticola & A. actinomycetemcomitans \\
\hline
\end{tabular}

test membranes at day 3 (Table 1). By day 3 these bacteria completely covered the membranes (Fig. 1). Bacterial colonies extending out from the membrane surfaces were especially heavy with $S$. mutans, $S$. sanguis, and $A$. viscosus. None of the three spirochetes ( $T$. denticola, $T$. vincentii, $T$. pectinovorum) were found to adhere to any of the three materials.

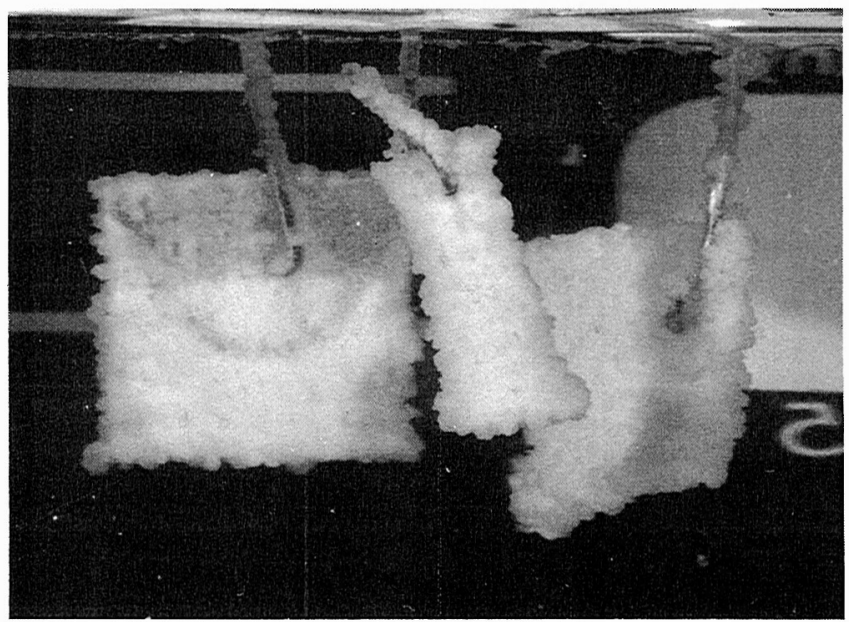

Figure 1. The adherence of $\mathrm{S}$. mutans to GTR membranes after 3 days of incubation. Membranes from the left to the right are: ePTFE, polyglactin 910 , and collagen. 


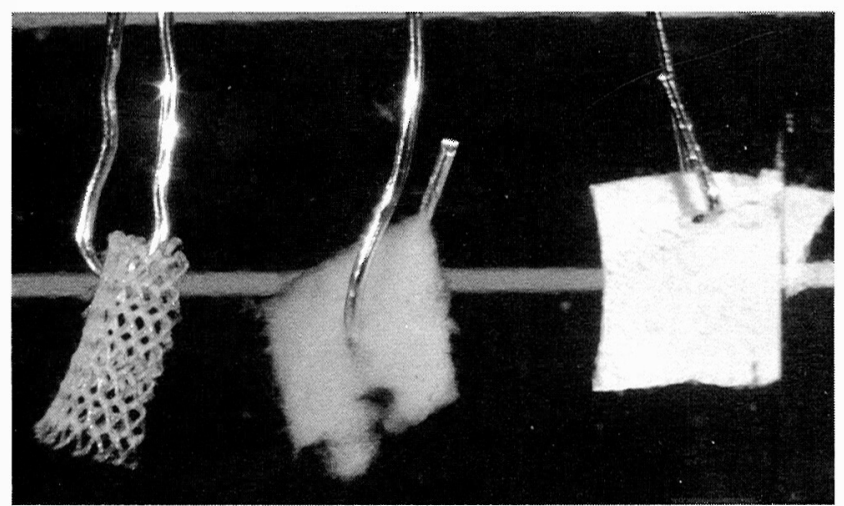

Figure 2. The collagen membrane (middle) started to disintegrate after 3 days of incubation with P. gingivalis. Left: Polyglactin 910. Right: ePTFE.

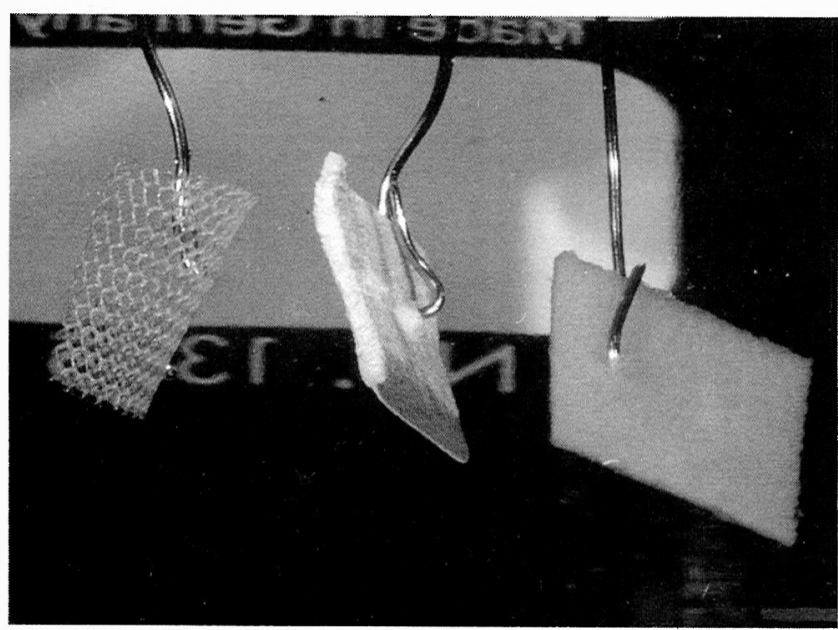

Figure 3. Control bottle without bacteria on day 35. Membranes from the left to the right are: polyglactin 910, ePTFE, and collagen.

The collagen membranes were degraded by $P$. gingivalis, $P$. melaninogenica, and $T$. denticola, while the polyglactin
910 specimens were degraded by $C$. albicans, $P$. melaninogenica, and $A$. actinomycetemcomitans (Table 2). In $P$. gingivalis, the collagen membranes started disintegrating by day 3 (Fig. 2) and were dissolved completely by day 5 . In contrast, while bacterial colonization increased with time, none of the ePTFE membranes demonstrated degradation during the 35 days of this experiment. Materials in the control bottles of media without microbes remained unchanged except that the collagen membranes appeared swollen due to liquid absorption (Fig. 3).

\section{Part II. Quantitative Analysis of Microbial Adherence, Bacterial Adherence to different membranes}

ePTFE. As shown in Table 3, at 4, 6, 12, and 24 hours, $S$. mutans adherence was significantly greater than the other five bacteria $(P<0.05)$. The other 5 bacteria $(P$. gingivalis, $A$. viscosus, $A$. actinomycetemcomitans, $F$. nucleatum and Selenomonas $s p$.) did not show any significant differences from each other except at 6 and 24 hours.

Polyglactin 910 (Table 4). P. gingivalis attachment was greatest when compared to the other 5 microorganisms at 4 hours with statistically significant $(P<0.05)$ differences between $P$. gingivalis and A. actinomycetemcomitans, Selenomonas sputigena, and $F$. nucleatum. At 6 hours, the adherence ability was as follows: $P$. gingivalis $>S$. mutans $>$ A. viscosus $>A$. actinomycetemcomitans $>F$. nucleatum $>$ Selenomonas sputigena, $P$. gingivalis and $S$. mutans attachments were significantly higher $(P<0.05)$ than the other 4 bacteria. At 12 hours, the attachment of $S$. mutans was significantly higher than the other bacteria. No significant differences were noted among the remaining 5 bacteria. At 24 hours, $S$. mutans exhibited significantly greater adherence than the other bacteria while $A$. actinomycetemcomitans surpassed $P$. gingivalis to have the second highest adherence counts.

Collagen membrane (Table 5). P. gingivalis adherence was significantly greater than the other bacteria while $S$.

Table 3. Comparison of Bacterial Adherence* to ePTFE membrane

\begin{tabular}{|c|c|c|c|c|c|c|}
\hline \multirow[t]{2}{*}{ Time } & \multicolumn{6}{|c|}{ Bacterium } \\
\hline & Selenomonas & F. nucleatum & A. $a$ & A. viscosus & $P$. gingivalis & S. mutans \\
\hline 4 hours & $0.17 \pm 0.07$ & $0.22 \pm 0.04$ & $0.39 \pm 0.14$ & $0.44 \pm 0.17$ & $0.72 \pm 0.08 \dagger$ & $2.25 \pm 0.31$ \\
\hline 6 hours & $\begin{array}{c}\text { Selenomonas } \\
0.28 \pm 0.27\end{array}$ & $\begin{array}{c}\text { A. } a \\
0.44 \pm 0.17\end{array}$ & $\begin{array}{l}\text { A. viscosus } \\
0.50 \pm 0.14\end{array}$ & $\begin{array}{c}F . \text { nucleatum } \\
0.69 \pm 0.22\end{array}$ & $\begin{array}{l}\text { P. gingivalis } \\
3.16 \pm 0.20\end{array}$ & $\begin{array}{l}\text { S. mutans } \\
5.30 \pm 0.54\end{array}$ \\
\hline 12 hours & $\begin{array}{c}\text { Selenomonas } \\
0.28 \pm 0.08\end{array}$ & $\begin{array}{l}\text { A. viscosus } \\
0.66 \pm 0.00\end{array}$ & $\begin{array}{c}\text { A. } a \\
0.88 \pm 0.14\end{array}$ & $\begin{array}{c}F . \text { nucleatum } \\
2.08 \pm 0.77\end{array}$ & $\begin{array}{l}P . \text { gingivalis } \\
5.80 \pm 0.60\end{array}$ & $\begin{array}{l}\text { S. mutans } \\
58.4 \pm 4.30\end{array}$ \\
\hline 24 hours & $\begin{array}{c}\text { Selenomonas } \\
0.30 \pm 0.04\end{array}$ & $\begin{array}{c}\text { F. nucleatum } \\
2.92 \pm 0.21\end{array}$ & $\begin{array}{l}\text { A. viscosus } \\
4.76 \pm 0.46\end{array}$ & $\begin{array}{c}P . \text { gingivalis } \\
6.93 \pm 0.41\end{array}$ & $\begin{array}{c}\text { A. } a \\
7.18 \pm 0.47\end{array}$ & $\begin{array}{l}\text { S. mutans } \\
89.36 \pm 2.17\end{array}$ \\
\hline
\end{tabular}

Means with dotted line have no statistically significant difference at $P<0.05$ level.

"The bacterial adherence counts are represented as means $\pm \mathrm{SD} \times 10^{7}$ cells $/ \mathrm{cm}^{2}$. 
Table 4. Comparison of Bacterial Adherence* to Polyglactin 910 Membrane

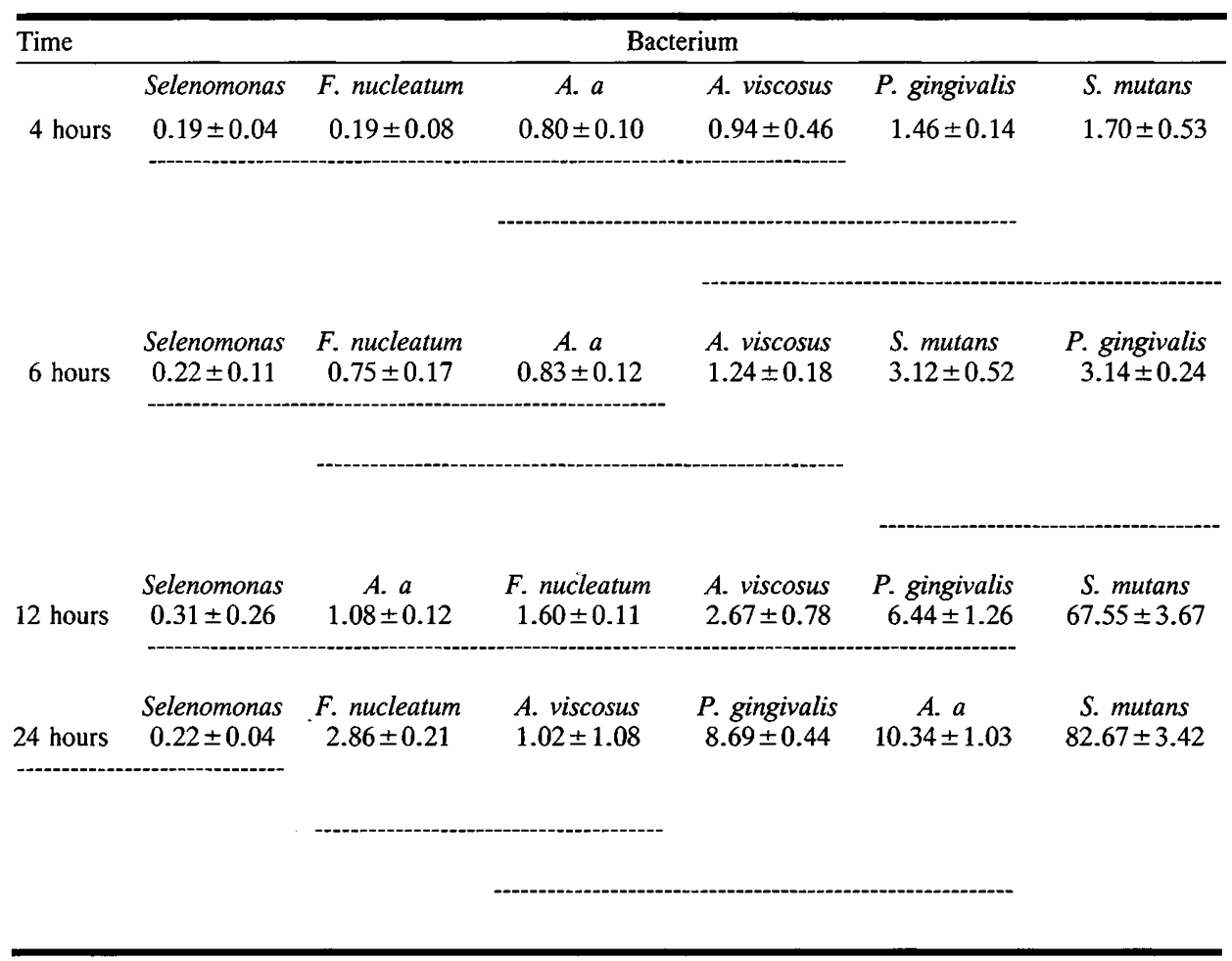

*The bacterial adherence counts are represented as means $\pm \mathrm{SD} \times 10^{7}$ cells $/ \mathrm{cm}^{2}$.

Means with the dotted line have no statistically significant difference at $P<0.05$ level.

Table 5. Comparison of Bacterial Adherence* to Collagen Membrane

\begin{tabular}{|c|c|c|c|c|c|c|}
\hline \multirow{2}{*}{$\begin{array}{l}\text { Time } \\
\text { hours }\end{array}$} & \multicolumn{6}{|c|}{ Bacterium } \\
\hline & $\begin{array}{c}\text { Selenomonas } \\
0.22 \pm 0.11\end{array}$ & $\begin{array}{c}F . \text { nucleatum } \\
0.47 \pm 0.15\end{array}$ & $\begin{array}{c}\text { A. } a \\
0.75 \pm 0.12\end{array}$ & $\begin{array}{l}\text { A. viscosus } \\
1.05 \pm 0.44\end{array}$ & $\begin{array}{l}\text { S. mutans } \\
2.50 \pm 0.14\end{array}$ & $\begin{array}{r}P . \text { gingivalis } \\
5.83 \pm 0.14\end{array}$ \\
\hline 6 hours & $\begin{array}{c}\text { Selenomonas } \\
0.25 \pm 0.00\end{array}$ & $\begin{array}{c}F . \text { nucleatum } \\
0.69 \pm 0.08\end{array}$ & $\begin{array}{c}\text { A. } a \\
0.91 \pm 0.07\end{array}$ & $\begin{array}{c}\text { A. viscosus } \\
1.43 \pm 0.22\end{array}$ & $\begin{array}{l}\text { S. mutans } \\
5.53 \pm 0.30\end{array}$ & $\begin{array}{c}P . \text { gingivalis } \\
15.1 \pm 0.56\end{array}$ \\
\hline 12 hours & $\begin{array}{c}\text { Selenomonas } \\
0.33 \pm 0.07\end{array}$ & $\begin{array}{c}A . a \\
1.16 \pm 0.34\end{array}$ & $\begin{array}{c}F . \text { nucleatum } \\
1.57 \pm 0.12\end{array}$ & $\begin{array}{c}\text { A. viscosus } \\
3.08 \pm 0.17\end{array}$ & $\begin{array}{l}P . \text { gingivalis } \\
20.96 \pm 0.38\end{array}$ & $\begin{array}{l}\text { S. mutans } \\
96.67 \pm 1.67\end{array}$ \\
\hline 24 hours & $\begin{array}{c}\text { Selenomonas } \\
0.25 \pm 0.07\end{array}$ & $\begin{array}{c}F . \text { nucleatum } \\
3.17 \pm 0.11\end{array}$ & $\begin{array}{l}\text { A. viscosus } \\
6.59 \pm 0.21\end{array}$ & $\begin{array}{c}\text { A.a } \\
10.45 \pm 0.33\end{array}$ & $\begin{array}{l}\text { P. gingivalis } \\
38.58 \pm 3.93\end{array}$ & $\begin{array}{c}\text { S. mutans } \\
119.52 \pm 4.3\end{array}$ \\
\hline
\end{tabular}

Means with dotted line have no statistically significant difference at $P<0.05$ level.

${ }^{*}$ The bacterial adherence counts are represented as means \pm SD $\times 10^{7} \mathrm{cells} / \mathrm{cm}^{2}$.

mutans showed the second highest attachment. Similar findings were observed at 6 hours. After 12 hours of incubation, the adherence of $S$. mutans to the collagen membrane surpassed $P$. gingivalis. A significant difference ex- isted between $S$. mutans and $P$. gingivalis at this time. Both bacteria demonstrated significantly higher levels of attachment than did the other four test organisms. The same pattern was noted at 24 hours as at 12 hours except for $A$. 
Table 6. $P$. gingivalis Adherence* to GTR Membranes

\begin{tabular}{|c|c|c|c|}
\hline \multirow{2}{*}{$\frac{\text { Time }}{4 \text { hours }}$} & \multicolumn{3}{|c|}{ Material } \\
\hline & $\begin{array}{c}\text { ePTFE } \\
0.72 \pm 0.08\end{array}$ & $\begin{array}{c}\text { Polyglactin } 910 \\
1.68 \pm 0.53\end{array}$ & $\begin{array}{c}\text { Collagen } \\
5.83 \pm 0.14\end{array}$ \\
\hline 6 hours & $\begin{array}{c}\text { Polyglactin } 910 \\
3.14 \pm 0.24\end{array}$ & $\begin{array}{c}\text { ePTFE } \\
3.17 \pm 0.20\end{array}$ & $\begin{array}{c}\text { Collagen } \\
15.10 \pm 0.55\end{array}$ \\
\hline 12 hours & $\begin{array}{c}\text { ePTFE } \\
5.81 \pm 0.61\end{array}$ & $\begin{array}{c}\text { Polyglactin } 910 \\
6.44 \pm 1.26\end{array}$ & $\begin{array}{c}\text { Collagen } \\
20.96 \pm 0.38\end{array}$ \\
\hline 24 hours & $\begin{array}{c}\text { ePTFE } \\
6.94 \pm 0.41\end{array}$ & $\begin{array}{c}\text { Polyglactin } 910 \\
8.69 \pm 0.44\end{array}$ & $\begin{array}{c}\text { Collagen } \\
38.58 \pm 3.93\end{array}$ \\
\hline
\end{tabular}

Means with dotted line have no statistically significant difference at $P$ $<0.05$ level.

*The bacterial adherence counts are represented as means $\pm \mathrm{SD} \times 10^{7}$ cells $/ \mathrm{cm}^{2}$.

actinomycetemcomitans which had a significantly higher adherence score than Selenomonas sputingea.

Part II: Quantitative Analysis of Microbial Adherence: Adherence Ability of Individual Bacterial Species to the GTR Membranes

A. actinomycetemcomitans. Adherence of A. actinomycetemcomitans to $\mathrm{PTTE}$ was significantly lower than to the polyglactin 910 and collagen at $6(0.44 \pm 0.11$ vs $0.83 \pm 0.12$ and $0.90 \pm 0.07)$ and $24(7.18 \pm 0.47$ vs $10.43 \pm 1.03$ and $10.45 \pm 0.33$ ) hours.

A. viscosus. At 6 and 12 hours, the attachment of $A$. viscosus to ePTFE was significantly lower than for the other two materials.

F. nucleatum and Selenomonas. There were no significant differences in the adherence of these bacterial species to different biomaterials at any time point.

$\boldsymbol{P}$. gingivalis. The order of the attachment scores for $P$. gingivalis to the 3 membranes was similar at all time points as shown in Table 6. $P$. gingivalis adhere was significantly higher to the collagen membrane compared to the other two materials.

S. mutans. At 4 and 6 hours, the adherence scores of $S$. mutans to polyglactin 910 was significantly lower than for ePTFE and the collagen membrane (Table 7). No significant differences were noted between ePTFE and the collagen membrane before 6 hours of incubation. However, at 12 and 24 hours of incubation, $S$. mutans adhered significantly more to the collagen membrane than to the other materials.

\section{DISCUSSION}

The adhesion of bacteria to mammalian tissue surfaces and biomaterials has been recognized as an important initial step in the pathogenesis of infection. ${ }^{5,8}$ Qualitative observation
Table 7. S. mutanus Adherence* to GTR Membranes

\begin{tabular}{|c|c|c|c|}
\hline \multicolumn{4}{|l|}{ Time } \\
\hline 4 hours & $\begin{array}{c}\text { Polyglactin } 910 \\
1.46 \pm 0.14\end{array}$ & $\begin{array}{c}\text { ePTFE } \\
2.25 \pm 0.31\end{array}$ & $\begin{array}{l}\text { Collagen } \\
2.51 \pm 0.14\end{array}$ \\
\hline 6 hours & $\begin{array}{c}\text { Polyglactin } 910 \\
3.12 \pm 0.51\end{array}$ & $\begin{array}{c}\text { ePTFE } \\
5.29 \pm 0.54\end{array}$ & $\begin{array}{l}\text { Collagen } \\
5.53 \pm 0.30\end{array}$ \\
\hline 12 hours & $\begin{array}{c}\text { ePTFE } \\
58.39 \pm 4.30\end{array}$ & $\begin{array}{c}\text { Polyglactin } 910 \\
67.55 \pm 3.63\end{array}$ & $\begin{array}{c}\text { Collagen } \\
96.67 \pm 1.67\end{array}$ \\
\hline 24 hours & $\begin{array}{c}\text { Polyglactin } 910 \\
82.68 \pm 3.42\end{array}$ & $\begin{array}{c}\text { ePTFE } \\
89.36 \pm 2.17\end{array}$ & $\begin{array}{c}\text { Collagen } \\
119.52 \pm 4.30\end{array}$ \\
\hline
\end{tabular}

Means with dotted line have no statistically significant difference at $P$ $<0.05$ level.

$*$ The bacterial adherence counts are represented as means $\pm \mathrm{SD} \times 10^{7}$ cells $/ \mathrm{cm}^{2}$.

from our study demonstrated that, of the microbes tested, $S$. mutans, $S$. sanguis, $A$. viscosus, $P$. melaninogenica, and Selenomonas sputigena could colonize all test materials by 3 days (Table 1). Studying oral bacterial adherence on tooth surfaces, Brecx et al. ${ }^{6}$ found that the majority of the increase in the microbial mass comes from bacteria already present on the tooth surface and they in turn provided the basis of co-aggregation by secondary bacteria species. ${ }^{6}$ Early bacterial adhesion seems to be more important than secondary accumulation. ${ }^{6}$ Therefore, this study only examined early bacterial adhesion.

Results from this study indicated $P$. gingivalis, $P$. melaninogenica, and $T$. denticola can adhere and degrade barrier membranes, particularly the absorbable types. $P$. gingivalis is known to produce collagenases and is thought to be involved in the degradation of connective tissues in periodontal diseases. ${ }^{8}$ Our results supported the finding of Mayrand and Grenier ${ }^{9}$ who tested collagenolytic activity of 12 species of oral bacteria and found that $P$. gingivalis had the strongest ability to degrade collagen matrix.

Data from this study demonstrated that $P$. gingivalis dissolved the collagen membrane completely within 4 to 5 days while $P$. melaninogenicua and $T$. denticola degraded the material at a slower rate. Similar findings were also reported by Mayrand and Grenier ${ }^{9}$ except in their study $A$. actinomycetemcomitans and $F$. nucleatum had weak collagenolytic activity. This may be due to differences in techniques used to evaluate the result as in this study visual observation was used while they used a biochemical assay. Collagen membranes have been observed to attract bacteria in both in vivo or in vitro studies $\mathbf{1 0}^{\mathbf{1 0}}$ and our findings agree. Electron micrographs have demonstrated bacteria in intimate contact with acellular cartilage matrix surface, particularly with collagen fibers. ${ }^{10,13} P$. gingivalis bound rapidly to hydroxyapatite beads treated with human type I or 
type IV collagen when compared to hydroxyapatite beads without collagen treatment. ${ }^{11}$ Other in vitro studies also have demonstrated that collagen promotes adhesion of $A$. viscosus, Streptococcus spp., and Staphylococcus spp. ${ }^{12-14}$

ePTFE was not degraded by any microorganisms during the entire 35 day experiment period. This finding can be explained on the basis of its nonabsorbable properties. However, bacteria did adhere to the ePTFE membrane in our experiments. Passariello et al. ${ }^{15}$ reported bacterial colonization in all 16 patients who underwent periodontal regeneration procedures by implantation of ePTFE. Furthermore, Selvig et al. ${ }^{4}$ using SEM, observed bacterial contamination of ePTFE membranes. A major drawback of a nonabsorbable material is the inconvenience of the secondary surgery. ${ }^{16}$ However, membranes that are removed may have an advantage if a membrane-associated infection occurs. Because it has been shown that bacteria within biofilms are inherently resistant to antibiotic therapy, the treatment of choice for recurrent biomaterial infection is by removal of the biomaterial. ${ }^{17}$

Polyglactin 910 had significantly lower $S$. mutans adherence than either collagen or ePTFE membranes at all time periods except 12 hours. $P$. gingivalis demonstrated a stronger adherence ability than the other 5 bacteria at 4 and 6 hours. However, $S$. mutans showed a strong adherence at 12 and 24 hours (Table 4). Resorption of polyglactin 910 has been reported mainly due to hydrolyzing of its ester bonds and not to be a result of enzyme degradation. ${ }^{18}$ Our results indicated that $C$. albicans, $P$. melaninogenica, and A. actinomycetemcomitans can resorb polyglactin 910 membrane in vitro. However, no research to date has investigated enzymatic resorption of polyglactin 910 by microorganisms. Therefore, it is not known if any enzymes secreted by microorganisms can accelerate the resorption of polyglactin 910 membranes.

Bacteria which were found to have high adherent ability, such as $S$. mutans, $S$. sanguis, $A$. viscosus, $P$. gingivalis, $P$. melaninogenica, and $P$. intermedia, secrete glycocalyx substances. Similar findings have been reported by Passariello et al. ${ }^{15}$ In their in vivo study, bacterial colonization on ePTFE membranes taken from periodontal regeneration procedures involved opportunistic glycocalyx-producing bacteria. The glycocalyx has been shown to be a virulence factor in pathogens as diverse as Actinomyces, Bacteroides, Haemophilus, Streptococcus, and Staphylococcus. ${ }^{19}$ It was suggested that once the bacteria are protected by a glycocalyx bio-film, they are highly resistance to antibacterial agents, such as bacteriophage, bacteriocins, surfactants, antibiotics, and phagocytic cells. ${ }^{18}$ Hence, a dilemma could result if antibiotic coverage is extended for high risk SBE patients with GTR treatment since prolonged antibiotic therapy may enhance the evolution of drug resistant bacteria while persistent bacteremia may be caused by the glycocalyx-producing bacteria. Therefore, the duration of anti- biotic prophylaxis for high risk patients during GTR procedures remains in question.

$S$. mutans and $P$. gingivalis were found to have the highest adherence counts in our investigation (Table 3, 4, and 5 ). Adherence of $S$. mutans to inorganic surfaces is mainly a result of a glucan-mediated interaction. ${ }^{20} S$. mutans can produce several types of polysaccharides which contribute to the binding of $S$. mutans cells to other cells. S. mutans can also bind to host proteins, such as fibronectin, salivary agglutinins, and aggregrated $\beta_{2}$-microglobulin. Furthermore, $S$. mutans has a cell surface galactose-specific lectin which links the organism to the pellicle and the plaque matrix by binding to extracellular substances containing carbohydrate. ${ }^{21}$ In addition to the strong adhesive ability, $S$. mutans has been associated with infectious endocarditis. The viridans group of streptococci is well known as the most common cause of bacterial endocarditis, accounting for approximately $45 \%$ to $50 \%$ of all cases when compared to non-enterococcal. ${ }^{22} S$. mutans possess a surface antigen also present in human heart, kidney and muscle tissues. Therefore, a newly developed $S$. mutans vaccine may cross react to heart and kidney tissues. ${ }^{23}$ Since the Streptococcus spp. were the predominant bacteria adhering to GTR membrane in our study, the potential hazard of $S$. mutans to heart and kidney tissues during the GTR procedure should be considered.

The limitation of this study related to the direct microscopic count of the individual cells in a microbial population. Direct microscopic count can be done by Petroff-Hausser chamber, hemocytometer, electronic counters (such as Coutler counter), and radio-labeled bacteria that are counted by scintillation. In this study, we used the Petroff-Hausser chamber to count the adherent number of bacteria. This method is fast and easy to perform; however, some drawbacks are present since it may count both living and dead bacteria. Artifacts may also be counted along with the cells under microscopic examination. Since small volumes $(0.02$ $\mathrm{ml}$ ) of solution were used, each bacterium seen in the chamber represents a very large number of microorganisms per $\mathrm{ml}$ of suspension. Hence a large number of microorganisms must be present in the population before they can be counted accurately. This technique cannot detect bacterial concentration under $5 \times 10^{4} \mathrm{cell} / \mathrm{ml}$ and the chance for errors gradually increases as bacterial concentrations approach this lower level.

Although bacteria demonstrated a stronger ability to attach to collagen or polyglactin 910 membranes than to ePTFE in this in vitro study, no research to date indicates that collagen or polyglactin 910 membranes would be more likely to cause gingival recession and/or membrane exposure. Therefore, the clinical significance of these findings remains to be clarified. Future studies should include an in vivo quantitative study designed to analyze oral bacterial adherence to different GTR materials and an investigation of GTR membranes coated with antibiotics for their effec- 
tiveness in reducing infection rate. Until research confirms that the GTR technique does not cause persistent bacteremia from microbial colonies protected by glycocalyx, GTR technique should be used with caution in patients at risk for infectious endocarditis.

From this in vitro study, the following conclusions can be drawn: 1) oral microorganisms vary in their ability to adhere to biomaterial membranes used for guided tissue regeneration. Certain microorganisms, such as $P$. gingivalis, $P$. melaninogenica, $T$. denticola, $A$. actinomycetemcomitans and $C$. albicans can adhere to and degrade absorbable materials used for GTR. 2) Polyglactin membranes have significantly $(P<0.05)$ lower $S$. mutans adherence than either ePTFE or collagen membranes at 4 and 6 hours. 3) Collagen membranes have significantly higher $S$. mutans attachment at 12 and 24 hours when compared to the other two membranes.

\section{Acknowledgment}

The authors thank Dr. Frederic Smith and Ms. Robin Gembacz for their assistance in the preparation of this manuscript. This study was supported, in part, by grant DE0866403A1 from the National Institute of Dental Research.

\section{REFERENCES}

1. Becker W, Becker BE, Handelsman M, et al. Guided tissue regeneration for implants placed into extraction sockets: A study in dogs. J Periodontol 1991;62:703-709.

2. Buser D, Bragger U, Lang NP, Nyman S. Regeneration and enlargement of jaw bone using guided tissue regeneration. Clin Oral Implant Res 1990;1:22-32.

3. Zablotsky M, Meffert R, Caudill R, Evans G. Histological and clinical comparisons of guided tissue regeneration on dehiscend hydroxylapatite-coated and titanium endosseous implant surfaces: A pilot study. Int J Oral Maxillofac Implants 1991;6:294-303.

4. Selvig KA, Nilveus RE, Fitzmorris L, et al. Scanning electron microscopic observations of cell population and bacterial contamination of membranes used for guided periodontal tissue regeneration in humans. J Periodontol 1990;61:515-520.

5. Gristina AG, Oga M, Webb LX, Hobgood CD. Adherent bacterial colonization in the pathogenesis of osteomyelitis. Science 1985;228:990-993.

6. Brecx M, Theilade J, Attstrom R. A ultrastructural quantitative study of the significance of microbial multiplication during early plaque growth. J Periodont Res 1983;18:177-186.

7. Selvig KA, Kersten B, Chamberlain DH, et al. Regeneration surgery of intrabony periodontal defects using ePTFE barrier membranes: Scanning electron microscopic evaluation of retrieved membranes versus clinical healing. J Periodontol 1992;63:974-978.

8. Gibbons RJ. Bacterial adhesion to oral tissues: A model for infectious diseases. J Dent Res 1989;68:750-760.

9. Mayrand D, Grenier D. Detection of collagenase activity in oral bacteria. Can J Microbiol 1985;31:134-138.

10. Voytek A, Gristina AG, Barth E, et al. Staphylococcal adhesion to collagen in intra-articular sepsis. Biomaterial 1988;9:107-110.

11. Naito Y, Gibbons RJ. Attachment of Bacteroides gingivalis to collagenous substrata. J Dent Res 1988;67:1075-1080.

12. Liu T, Gibbons RJ, Hay DI. Streptococcus cricetus and Streptococcus rattus bind to different segments of collagen molecules. Oral Microbiol Immunol 1990;5:143-148.

13. Hook M, McGavin MJ, Switalski LM, et al. Interactions of bacteria with extracellular matrix proteins. Cell Differ Dev 1990;32:433-438.

14. Liu T, Gibbons RJ, Hay DI, Skobe Z. Binding of Actinomyces viscous to collagen: Association with type 1 fimbrial adhesion. Oral Microbiol Immunol 1991;6:1-5.

15. Passariello $\mathrm{C}$, Thaller MC, Selan $\mathrm{L}$, et al. Periodontal regeneration procedures may induce colonization by glycocalyx-producing bacteria. Med Micro Immunol 1991;180:67-72.

16. Blumenthal NM. The use of collagen membranes to guide regeneration of new connective tissue attachment in dogs. $J$ Periodontol 1988;59:830-836.

17. Costerton JW, Marrie TJ, Cheng K-J. The sessile mode of bacterial growth. In: Savage DC, ed. Bacterial Adhesion. Mechanisms and Physiological Significance. New York: Plenum Press, 1985:3.

18. Miller RA, Brady JM, Curright DE. Degradation rates of oral resorbable implants (polylactates and polyglycolates): Rate modification with changes in PLA/PGA copolymer rations. $J$ Biomed Mater Res 1977;11:711-719.

19. Costerton JW, Irvin RT, Cheng KJ. The bacterial glycocalyx in nature and disease. Annual Rev Microbiol 1981;35:299-324.

20. Schilling KM, Bowen WH. Glucans synthesized in situ in experimental salivary pellicle function as specific bindings for Streptococcus mutans. Infect Immun 1992;60:284-295.

21. Christensen GD, Simpson WA, Beachey EH. Adhesion of bacteria to animal tissues: complex mechanisms. In: Savage DC, ed. Bacterial Adhesion. Mechanisms and Physiological Significance. New York: Plenum Press; 1985:279.

22. Ullman RF, Miller SJ, Strampfer MJ, Cunha BA. Streptococcus mutans endocardititis: Report of three cases and reviews of the literature. Heart Lung 1988;17:209-212.

23. Russell MW, Wu H-Y. Streptococcus mutans and the problem of heart cross-reactivity. Crit Rev Oral Biol Med 1990;1:191-205.

Send reprint requests to: Dr. Hom-Lay Wang, University of Michigan, School of Dentistry, 1011 North University Ave., Ann Arbor, Michigan 48109-1078.

Accepted for publication August 26, 1993. 